\title{
Diversity of tree flora in homegardens in urban proximity of Anuradhapura city, Sri Lanka
}

\author{
Chaminda Egodawatta", Rasika Warnasooriya \\ Email address: \\ egowcp@gmail.com (C. Egodawatta),wmrsanjee@gmail.com (R. Warnasooriya)
}

Department of Plant Sciences, Faculty of Agriculture, Rajarata University of Sri Lanka, Puliyankulama, Anuradhapura, Sri Lanka

To cite this article:

Chaminda Egodawatta, Rasika Warnasooriya. Diversity of Tree Flora in Homegardens in Urban Proximity of Anuradhapura City, Sri Lanka. Agriculture, Forestry and Fisheries. Vol. 3, No. 1, 2014, pp. 34-39. doi: 10.11648/j.aff.20140301.17

\begin{abstract}
It was hypothesised that the land ownership with clear titles has an influence on incorporating perennial tree flora. Hence, this study compares the types and density of tree species in homegardens of inherited and settled lands in close proximity of Anuradhapura city, with subsistence farming activities. Mean harvestable tree density was 54.5 trees/ac in inherited lands compared to 40.3 trees/ac in settled lands. In spite of the general similarity in tree flora between the two categories of homegardens, certain tree species are more abundant in one than the other. Exotic timber tree flora represented approximately $30 \%$ of total tree population in settled compared to $16 \%$ in inherited. Exotic timber tree flora mainly dominated by Tectona grandis and Berrya cordifolia in settled lands concerning more economic returns. In inherited lands, multipurpose trees i.e. Artocarpus heterophyllus, Azadirachta indica and Mangifera indica were highly abaundanat concering diversity and food security. Cocos nucifera was the most abaundant tree specis in both categories accounting more than $40 \%$ abaundance. Tree species such as Tamarindus indica was restricted to inherited lands and Felicium decipiens and Swietenia macrophylla to the settled lands. It is advocated that the settled farmers should preserve more diversity among trees as inherited farmers, which enhance food and economic security under diminishing climatic suitability for crop production. Nonetheless, this study awaked an important entity for future carbon crediting programmes, which would be a win-win situation in forestry and farming aspects.
\end{abstract}

Keywords: Inherited Lands, Settled Lands, Tree Flora

\section{Introduction}

Similar to most parts of humid tropics, shifting cultivation is the main system of food crop production in the dry zone of Sri Lanka for many years. Consequent development programmes under various settlement schemes, hence very rapid population increase and problems of economic pressure, food shortage and malnutrition, the traditional extensive system of shifting cultivation is gradually being replaced by continuous farming, which was observed in Asia and Africa [1]. These gradual changes are highly evident in urban fringe, around main cities in the dry zone. Around Anuradhapura, where both low-land and upland farming features in the agricultural economy, continuous upland farming is always linked to integrated multipurpose perennials. This development is particularly substantial within 10-20 km radius around a populated city like Anuradhapura. Significantly, high proportion of people engaged in off-farm income generation activities, rather than farming [2], however crop production generates considerable income as well. Unlike in commercial farmers in the dry zone, these continuous farming is not based on intensive annual crops production that is more alike of a mono-crop. Rather, it is based on some form of traditional agroforestry in which tree crop combinations that often found in homegardens [3]. Trees are a major component, with a vital role in erosion reduction, moisture and organic matter conservation, alternative food and nutrient supply and income generation [4]. Especially, perennials that are integrated into these systems are manly selected upon their economic value as timber. Simultaneously, multipurpose trees also show a similar abundance and similar value. Major examples are Cocos nucifera and Artocarpus heterophyllus. Hence, these systems are interesting entities to explore as an agroforestry system that is interwoven with development and urbanization of rural agri-sector.

Studies on agroforestry systems of Sri Lanka tended to focus on alley cropping [5], traditional forest gardens [6], 
homegardens, plantation forests [7] and specific agro-silvi-pastoral systems under coconut. There are no documented accounts of trees in traditional agroforestry systems associated to different land ownership systems in the dry zone. Further, quantitative data on the density, diversity and frequency of multipurpose and timber tree species in upland homegardens with continuous cultivation is practised, are lacking. The present study focused on the timber and multipurpose trees occurring in the homegardens of inherited and settled lands within a closer proximity to Anuradhapura city. It seeks to ascertain whether differences in ownership of lands in a limited area with uniform climate are reflected in the types and density of trees allowed to grow or deliberately incorporated by the farmer on their upland homegardens.

\subsection{Study Area}

The present study was carried out in farmlands at fringe of the Anuradhapura city, Sri Lanka $\left(8.3500^{\circ} \mathrm{N}, 80.3833^{\circ} \mathrm{E}\right)$ adjoining to rural landscape within $10-20 \mathrm{~km}$ proximity. The area is characterized by a humid equatorial climate with a distinct wet and dry season, the latter being usually much longer than the former. The annual rainfall is $<1300 \mathrm{~mm}$ with most of the rains concentrated in the North-East monsoon season lasting from December - February. The rainfall regime is bi-annual with double peaks corresponding to North-East and South-West monsoons. Latter brings either less or no rains causing an extended dry spell in between 3-6 months. The annual temperature ranges between $25-33{ }^{0} \mathrm{C}$ without significant seasonal or monthly variations. This location belongs to $\mathrm{DL}_{1 \mathrm{~b}}$ agro- ecological region [8].

Regional vegetation is dry mixed evergreen forests. The study region is drier than the rural regions in surrounding, which are with provisions of more moisture through tank cascade system. Mainly, native timber trees such as Drypetes sepiaria, Manilkara hexandra, Chloroxylon swietenia and Berrya cordifolia, multipurpose trees such as Azadirachta indica and Artocarpus heterophyllus, fruit trees such as Mangifera indica and Anchardium occidentale are predominant. Over much of the area, secondary forests are replaced with development and farming activities, specially farming of field crops such as maize, low country vegetables and root and tubers. Successional fallow communities occur in undisturbed outskirts are inhabited majorly by non-indigenous invasive species.

Anuradhapura area is a rolling plain with an average elevation of 70-80 $\mathrm{m}$ above mean sea level. The area is underlain by basement of complex rocks, especially quartz and sedimented rocks. These have weathered to give rise to soils with coarse textured subsoil layer and clay-enriched surface layer. They are Reddish Brown Earth (RBE) according to Sri Lankan taxonomy [9] or Rhodustalf in USDA soil taxonomy [10]. These soils are poor in nutrients, especially organic matter and nitrogen as most a typical tropical soils [11].

\section{Materials and Methods}

Farms that are cultivated as homegardens every year were selected from outskirts of Anuradhapura city, especially within villages included in the University Village programme [a knowledge and experience sharing programme on agriculture between famer community and university]. One major character used in selection was the presence of multipurpose perennials and timber trees. Two major categories of land ownership were inherited and settled lands [12]. Inherited lands have clear titles and these lands were occupied and utilized for few decades. Hence lands were transferred within a single family for generation to generation. Settles lands were recent establishments, hence utilized for lesser number of years than former. At the same time, there are no clear titles for land than a permission to utilize, however these lands are owned by $1^{\text {st }}$ or $2^{\text {nd }}$ generation of the farm family. Both types of homegardens are utilizing for cropping with greater heterogeneity. Nevertheless, diversity of annuals within homegardens is considerably similar despite some differences due to socio-economic background of the household.

Recent high resolution satellite images or aerial photographs of the study area were not available to serve as a sampling frame to assist in the random selection of homegardens. Hence, selection of homegardens for study was based on the researcher's discretion. Field visits were made to homegardens of the study region area for the purpose of sampling inherited and settled lands. Homegardens were chosen after they were inspected in the field and it was ascertained that lands were used for homegardening and that they were located on similar topographic position. It was important that both inherited and settled land were located on comparable topographic location to ensure that changes in soil characteristics along the catena or variations in ground drainage did not exert a significant influence on the types of trees growing or allowed to grow on the homegardens alongside food crops. Land title was recorded through a socio-economic survey, which was conducted simultaneously.

The quadrat approach was adopted in measuring tree species and populations in the homegarden. In each homegarden studied, a quadrat of $25 \mathrm{~m} \times 25 \mathrm{~m}$ was delimited in order to determine tree density [subsequently converted into density per acre], number of individuals belonging to each tree species, tree species diversity and number of tree species. The sample plot was large enough to enclose an adequate number of tree individuals belonging to different species for the purpose of quantitatively assessing the number of tree species. Further, for large homegardens, several sample plots were used to obtain a mean.

Only woody perennials of erect habit with girth at breast height of at least $10 \mathrm{~cm}$ were enumerated. Thirty sample plots were studied for inherited homegardens farms and another 30 for settled homegardens, making a total of 60 plots. Tree species diversity was determined as the 
reciprocal of Simpson's index [13, 14], while species frequency was determined for each of the two types of homegardens by expressing the number of plots in which the species in question was observed as a percentage of the total number of plots studied for each of the two categories of farms. This approach was adopted because the plots studied for each of the two categories of homegardens are not contiguous. Sorenson's index [15] was used to assess the degree of similarity of the tree flora of the two categories of homegardens studied.

\section{Results and Discussion}

\subsection{Tree Density and Tree Species in Farms}

Certain timber tree species were common to both inherited and settled homegardens. Such trees were Tectona grandis, Berrya cordifolia and Azadirachta indica. These trees were deliberately integrated to the homegarden for the purpose of using them for timber for either in-house use or commercial trading. The tree species that are most frequently encountered in many homegardens in the dry zone are not necessarily having the highest frequency of occurrence in the homegardens. Interestingly, multipurpose trees showed the highest and most frequent occurrence in contrast (Table 01). Species such as Cocos nucifera, Artocarpus heterophyllus and Mangifera indica were common to a greater extent. Further, typical multipurpose tresses such as Gliricidia sepium or Leucaena leucocephala were showed a less abundance as well as less frequency in both homegarden systems and specially observed along with the fencing. Also, the frequency of Diospyros ebenum and Chloroxylon swietenia, which are regarded as highly valued timber species were below $5 \%$ in both categories of homegardens. However, such Berrya cordifolia also had a high frequency of at least $65 \%$ in each of the two categories of homegardens (Table 01) despite it was a recent introduction to the dry zone.

Table 01. Frequency of tree species (percentage of quadrats) in inherited and settled homegardens near Anuradhapura city.

\begin{tabular}{lcc}
\hline Tree species $^{\text {a }}$ & $\begin{array}{c}\text { Inherited } \\
\text { homegardens (\%) }\end{array}$ & $\begin{array}{c}\text { Settled } \\
\text { homegardens (\%) }\end{array}$ \\
\hline Cocos nucifera & 98 & 90 \\
Tectona grandis & 87 & 96 \\
Azadirachta indica & 82 & 68 \\
Mangifera indica & 69 & 72 \\
Artocarpus heterophyllus & 65 & 44 \\
Anacardium occidentale & 54 & 46 \\
Berrya cordifolia & 38 & 65 \\
Leucaena leucocephala & 12 & 41 \\
Gliricidia sepium & 10 & 29 \\
Swietenia macrophylla & 2 & 28 \\
Tamarindus indica & 18 & 1 \\
\hline
\end{tabular}

${ }^{a}$ Only species with a minimum frequency of occurrence of $10 \%$ in at least one of the two categories of homegardens are included in this table.
The frequency of Tectona grandis was approximately similar in inherited and settled homegardens. This notwithstanding, some tree species were more frequently incorporated in one homegarden system than the other. The frequency of Azadirachta indica was strikingly higher in the inherited homegardens and Tectona grandis and Berrya cordifolia higher in the settled homegardens (Table 01). A few trees occurring in the homegardens were not accidental occurrence, but deliberately introduced with certain choice of selection. They were Felicium decipiens, Vitex altissima, Mangifere indica and Anacardium occidentale. With exception $F$. decipiens and $V$. altissima, these are timber trees of importance for farmers in more economic context. Both $F$. decipiens and $V$. altissima are exotic trees. The latter was naturaliezed for centuries while the former was introduced recenlty.

The species that characteristically occur in deciduous dry forests were absent in both homegarden systems. Trees such as Drypetes sepiaria, Manilkara hexandra and Madhuca longifolia that characterized dry deciduous forests were no or rarely observed in both homegardens, however these were common in government reservations and common pasture lands in surrounding.

This indicates that under the present farming conditions with small land holding sizes, the regeneration of natural forest trees is inhibited. This is mainly due to lack of economic concerns, longer growth duration and legislative control on harvesting. Again, lack of propagation materials may have influence even if there is an interest. Even in surrounding forest reservations these trees were lacking due to widespread deforestation and due to site burning prior to cultivation which destroys soil seeds bank of these trees.

Aligns to expectation, tree density was much higher in the inherited homegardens (Table 02). The mean density of timber and multipurpose trees in the inherited homegardens at the urban fringe was approximately $35 \%$ greater that of settled homegardens in same surrounding. The most abundant tree in the inherited and settled homegardens was C. nucifera, with a density of slightly higher i.e. 8.4 trees/ac in latter and 6.5 trees/ac in the former. Moreover, $C$. nucifera accounted $11.9 \%$ of total tree flora in inherited homegeradens while it was $20.8 \%$ in settled homegardens (Tables 03). This would explain with the dietary habit of Sri Lankan, who are using coconut in substantial amounts in cooking. Hence, having sufficient number of nut producing coconut trees guarantee food security in to some extent, while selling extra may produce, a good income as well.

T. grandis was the most abundant tree species in the inherited homegardens, accounting for $19.4 \%$ of all the trees there, suggesting the perception of older generation towards timber. It is also an important element of the tree flora of the settled homegardens in which it was the second most abundant timber tree third overall (Table 03). B. cordifolia was the second most abundant tree in the settled homegardens. B. cordifolia showed a density of 6.7 trees/ac and it accounted for $16.6 \%$ of all trees enumerated in the settled homegardens. Although, tree density was 
significantly lower in the settled homegardens $(p<0.01)$, the density of the $B$. cordifolia was considerably higher there too (Table 02). Further, both $T$. grandis and $B$. cordifolia collectively had a similar density and similar proportion in both homegardens (Table 02 and 03).

Table 02. Density of trees and mean tree species per acre and tree species diversity in inherited and settled homegardens near Anuradhapura city.

\begin{tabular}{lccc}
\hline & $\begin{array}{c}\text { Inherited } \\
\text { homegardens } \\
(\boldsymbol{n}=30)\end{array}$ & $\begin{array}{c}\text { Settled } \\
\text { homegardens } \\
(\boldsymbol{n}=30)\end{array}$ & $\begin{array}{c}\text { t- } \\
\text { value }\end{array}$ \\
\hline Tree density & $54.5 \pm 10.4$ & $40.3 \pm 12.5$ & $7.7^{* *}$ \\
Cocos nucifera & 6.5 & 8.4 & $3.4^{* *}$ \\
Tectona grandis & 10.6 & 5.2 & $6.7^{* *}$ \\
Azadirachta indica & 3.2 & 4.3 & $2.5^{*}$ \\
Mangifera indica & 5.0 & 5.0 & $1.4 \mathrm{NS}$ \\
Artocarpus heterophyllus & 3.6 & 3.1 & $1.7 \mathrm{NS}$ \\
Anacardium occidentale & 3.5 & 2.6 & $2.1 \mathrm{NS}$ \\
Berrya cordifolia & 4.5 & 6.7 & $2.8^{*}$ \\
Leucaena leucocephala & 5.3 & 2.8 & $6.6^{* *}$ \\
Gliricidia sepium & 3.5 & 1.2 & $3.4^{* *}$ \\
Swietenia macrophylla & 0 & 1.8 & $2.2^{*}$ \\
Tamarindus indica & 2.5 & 0 & $4.1^{* *}$ \\
Chloroxylon swietenia & 2.1 & 1.5 & $2.0 \mathrm{NS}$ \\
Manilkara hexandra & 1.0 & 1.0 & $1.1 \mathrm{NS}$ \\
Diospyros ebenum & 1.0 & 0 & 1.7 \\
Tree species diversity (\%) & $21.5 \pm 2.4$ & $16.9 \pm 3.4$ & $5.8^{* *}$ \\
Mean number of trees per & $2.8 \pm 2.0$ & $2.5 \pm 2.0$ & $1.9 \mathrm{NS}$ \\
plot (per plot of 625 m $\left.{ }^{*}\right)$ & & & \\
\hline
\end{tabular}

NS: difference is not significant. ${ }^{*} p<0: 05 ; \stackrel{* *}{p}<0: 01$.

Table 03. Proportion (\%) of trees in homegardens that various species account for in inherited and settled homegardens near Anuradhapura city.

\begin{tabular}{lccc}
\hline & $\begin{array}{c}\text { Inherited } \\
\text { homegardens } \\
(\mathbf{n = 3 0 )}\end{array}$ & $\begin{array}{c}\text { Settled } \\
\text { homegardens } \\
(\boldsymbol{n}=30)\end{array}$ & $\begin{array}{c}\text { t- } \\
\text { value }\end{array}$ \\
\hline Cocos nucifera & 11.9 & 20.8 & $8.6^{* *}$ \\
Tectona grandis & 19.4 & 12.9 & $6.5^{* *}$ \\
Azadirachta indica & 5.9 & 10.7 & $4.6^{* *}$ \\
Mangifera indica & 9.2 & 12.4 & $2.0 \mathrm{NS}$ \\
Artocarpus heterophyllus & 6.6 & 7.7 & $1.7 \mathrm{NS}$ \\
Anacardium occidentale & 6.4 & 6.4 & $1.1 \mathrm{NS}$ \\
Berrya cordifolia & 8.3 & 16.6 & $4.1^{* *}$ \\
Leucaena leucocephala & 9.7 & 6.9 & $2.8^{* *}$ \\
Gliricidia sepium & 6.4 & 3.0 & $3.7^{* *}$ \\
Swietenia macrophylla & 0 & 4.5 & $5.0^{* *}$ \\
Tamarindus indica & 4.6 & 0 & $4.7^{* *}$ \\
Chloroxylon swietenia & 3.9 & 3.7 & $1.1 \mathrm{NS}$ \\
Manilkara hexandra & 1.8 & 2.5 & $2.1^{*}$ \\
Diospyros ebenum & 1.8 & 0 & $2.2^{*}$ \\
\hline
\end{tabular}

Only species that account for at least $1.5 \%$ of the trees in at least one of the two categories of homegardens are included in this table. NS: difference is not significant. ${ }^{*} \mathrm{p}<0: 05 ;{ }^{* *} \mathrm{p}<0: 01$.
It was found that the exotic timber trees in both inherited and settled homegardens are mainly those of direct economic value to the household. However, this difference may due to the farmer perception on each species. $T$. grandis was introduced earlier as a high valued timber species, however some critics are there on growing $T$. grandis in moisture limited soils later on. Without knowing the consequences earlier, farmers who were there (inherited land owners) grew $T$. grandis as an economically important crop. With some negative critic newly on $T$. grandis, new growers of timber trees showed same interest of growing timber trees with $B$. cordifolia, while leaving $T$. grandis in second.

The mean number of tree species did not vary significantly between the inherited and settled homegardens. However, tree species diversity was significantly lower in the settled homegardens, because they were recent establishments as well as preferential tree selection for growing [16].

Unlike in farms that grows annuls, live trees are an important feature of both homegardens in Anuradhapura area. This phenomenon was not only observed in Anuradhapura, Sri Lanka, but also studied in African region as well $[17,18]$. Trees are also a feature of native farms in Pacific Islands where, references [19] reported the occurrence of various trees, particularly fruit trees, in differently cropped and inhabited field crops such as Colocasia. In north-eastern Brazil, Orbignya phalerata is well integrated into the upland farming systems. Maize, cassava and beans are intercropped under O. Phalerata in fields cultivated under the system of shifting cultivation [20]. Hence, trees play an important role in these farming systems in Sri Lanka as well.

Furthermore, there was a keen interest on trees that can continuously support livelihood e.g. C. nucifera and some fruit trees rather than timber that only produce some substantial income with less frequency. However, mature / harvestable timber trees guarantee good income in an emergency.

\subsection{Similarity in Tree Flora}

Sorensen's index [15] was used to compare the flora of 30 pairs of serially corresponding plots under inherited and settled homegardens. The tree flora of the first inherited homegarden studied was compared with that of the first settled homegarden. Similarly, the second inherited homegarden was compared with the second settled homegarden and so on. The degree of similarity between the tree flora of the homegarden systems was moderate. Sorensen's index of similarity ranged from 0 to $60 \%$ with a mean of $28 \%$. The degree of similarity between the inherited and settled homegardens suggests that their tree flora tend to be quite distinctive, hence some tree species are more characteristic of one homegarden system than the other. The inherited homegardens were dominated by $T$. grandis while the most characteristic tree of the settled homegardens is $B$. cordifolia. Tree species such as Swietenia macrophylla 
were restricted in occurrence to the settled homegardens, while Tamarindus indica and Diospyros ebenum were only found in inherited homegardens. Mangifera indica and Artocarpus heterophyllus did not show a distinct affinity for any homegarden system, being an important feature of the flora of both homegardens due to its importance in food and economic security.

\section{Conclusions}

The density of live trees growing side-by-side with food crops was much higher in the inherited homegardens than in the settled homegardens at the urban fringe of Anuradhapura. This is contrary to what is to be expected as the natural regeneration of trees is severely reduced where permanent cropping is practised [21]. Farmers in both systems, having eliminated the secondary regeneration, appear to appreciate the value of trees in terms of food security and economic returns. Although the farmers, who practise continuous farming at separate upland and low lands, still preserve some indigenous secondary forest species in their homegardens [22], however they appear to favour exotic timber tree species which accounted approximately one third of the trees observed in the both homegarden systems. These species are incorporated truly for economic returns despite their influence to soil fertility, nutrient recycling and ground water status, which is still debatable. This is also evitable as similar importance was given to them even in inherited homegardens. However, some rare tree species are in the inherited homegardens in less frequency. Unlike many tropical upland farms, farmers in Anuradhapura are not interested of soil fertility improving agro-forestry trees such as G. sepium or $L$. leucocephala. This is not due to unawareness. Homegarden is not an important economic entity of these livelihoods, they have separate uplands or lowland, hence farmers do not make an effort enhancing the soil conditions of homegardens. Moreover, there are no direct economic returns from these species despite some uses.

Although, there are fewer trees in the settled homegardens than in the inherited homegardens, mean trees per plot studied was not significantly different. In addition, tree diversity of the latter was much greater then former. The possible intensification of trees with direct economic benefits, consequent up on increased economic security, will presumably lead to a reduction in tree species diversity as has occurred in settled homegardens at the urban fringe. The degree of similarity between the flora of the inherited and settled homegardens is low. Multipurpose trees are most characteristic and abundant tree species of the inherited homegardens, while exotic timber trees are the most diagnostic elements of the tree flora of the settled homegardens. As with other districts in Sri Lanka, increased demand for timber, consequent upon increasing middle class income, is accelerating the process of deforestation. The integration of trees into the homegardens, as is currently done by farmers in the study area, will relieve pressure on forests for timber, thereby helping to reduce the rate of deforestation. Interestingly with enhancing concerns on trees, climate change, carbon sequestration and carbon trading, these homegardens show an enormous potential. A homegardens solely may not an important entity, but collectively, both inherited and settled homegardens have different potentials in contributing global carbon sequestration. Hence, a comprehensive study shall be suggested to quantify carbon sequestration of these systems, which would be a livelihood supporting programme via carbon trading for the poor people in the dry zone.

\section{References}

[1] Lal, R. "Agricultural activities and the global carbon cycles". Nutrient Cycling in Agroecosystems Vol. 70, pp. 103-116, 2004.

[2] Burgers, P., Q.M. Ketterings and D.P. Garrity, "Fallow management strategies and issues in Southeast Asia". Agriculture Ecosystems and Environment, Vol. 110, pp. 1-13, 2005.

[3] Fernandes, E. C. M. and P. K. R. Nair, "An evaluation of the structure and function of tropical homegardens". ICRAF working paper no. 38, 1986.

[4] Brownrigg, L. Homegardening in international development: what the literature shows. The League for International Food Education, Washington, DC, 1985.

[5] De Costa, W.A.J.M. and U.R. Sangakkara, "Agronomic regeneration of soil fertility in tropical Asian smallholder uplands for sustainable food production. Centenary Review". Journal of Agricultural Science, Cambridge. vol. 114, pp. 111-133, 2006.

[6] Perera, A.H. and R.M.N. Rajapakse, "A baseline study of Kandyan forest gardens of Sri Lanka: structure, composition and utilization". Forest Ecology Management vol. 45, pp. 269-280, 1991.

[7] Evans, J. "Plantation forestry in the tropics, $2^{\text {nd }}$ edition". Oxford University Press, Oxford. UK, 2002.

[8] Panabokke C.R. "Soils and Agro-ecological environments of Sri Lanka. Natural Resources Series - No 2". Natural Resources, Energy and Science Authority, 47/5, Maitland Place, Colombo 7, 1996.

[9] Mapa, R. B., A.R. Dassanayake and H.B. Nayakekorale, "Soils of the Dry Zone of Sri Lanka, Special Publication No. 4". Soil Science Society of Sri Lanka, 2005.

[10] USDA Soil Taxonomy, Soil Survey Staff. "Keys to Soil Taxonomy, $10^{\text {th }}$ edition". USDA-Natural Resources Conservation Service, Washington, DC, 2006.

[11] Craswell, E.T. and R.D.B. Lefroy, "The role and function of organic matter in tropical soils". Nutrient Cycling in Agroecosystems vol. 61, pp. 7-18, 2001.

[12] Bloch, P. C. "Land tenure issues in Sri Lanka: A brief overview". USAID/Sri Lanka, Office of Food and Agriculture Development, Colombo, 1988.

[13] Simpson, E.H. Measurement of diversity. Nature [London] vol. 163 , pp. $688,1949$. 
[14] Odum, E.P. Ecology. Holt, Rinehart \& Winston. London, 1975.

[15] Sorenson, T. "A method for establishing groups of equal amplitude in plant sociology based on similarity of species content and its application to analyses of the vegetation on Danish commons". Biologiske Skrifter vol. 5, pp. 1-34, 1948.

[16] Nuberg, K. I., D.G. Evans and R. Senanayake, "Future of forest gardens in the Uvan uplands of Sri Lanka". Environmental Management vol. 18, pp. 794-813, 1994.

[17] Asare, E.O., S.K. Oppong and K. Twum-Ampofo, "Homegardens in the humid tropics of Ghana" in Tropical Homegardens, K. Landauer and M. Brazil, Eds., United Nations University: Tokyo, 1990, pp. 80-93.

[18] Okigbo, B.N. "Homegardens in tropical Africa" Tropical Homegardens by K. Landauer and M. Brazil, Eds., United Nations University, Tokyo, 1990, pp. 94-104.
[19] Falanruw, M.V.C, "The food production system of the Yap Islands" in Tropical Homegardens by K. Landauer and M. Brazil, Eds., United Nations University, Tokyo, 1990, pp. 94-104.

[20] May, P. H., A. B. Anderson, M. J. Balick, and M. F. Frazao "Subsistence Benefits from the Babassu Palm [Orbignya martiana]" Economic Botany, vol. 3, pp. 113-129, 1985.

[21] Steiner, K.G. "Overcoming soil fertility constraints to crop production in West Africa: impact of traditional and improved cropping systems on soil fertility" in Alleviating Soil Fertility Constraints to Increased Crop Production in West Africa, A.U. Mokwunye, Eds. Kluwer Academic Publishers, Dordrecht,1991, pp. 69-91.

[22] Halladay, P. and Gilmour, D. A. [1995] Conserving biodiversity outside the protected areas: The role of traditional agroecosystems. IUCN, Gland, 1995, pp. 65-78. 